\title{
STRATEGI PUBLIC RELATIONS DALAM MEMBANGUN HUBUNGAN DENGAN MEDIA
}

\author{
Evi Hafizah
}

\begin{abstract}
Abstrak
Membangun hubungan dengan media merupakan hal yang sangat penting bagi praktisi public relations. Keberhasilannya dalam melakukan tugas ke-PR-an dalam rangka menjangkau perhatian khalayak, sangat ditentukan oleh pemahamannya tentang strategi membangun hubungan dengan media serta kepandaian dan taktik praktisi public relations dalam membangun hubungan dengan media. Hubungan baik dengan media massa ini dibangun dengan menggunakan strategi komunikasi yang tepat, yaitu cara yang dilakukan demi kelancaran komunikasi antara public relations dengan media massa. Hubungan baik yang dimaksud disini adalah hubungan baik dengan institusi media dan antara public relations dengan wartawan. Hubungan yang baik dengan media massa menjadi satu hal yang sangat penting bagi seorang public relations. Seperti tentara yang akan maju untuk berperang, dia membutuhkan pengertian dan penguasaan tentang strategi perang. Begitu juga dengan praktisi public relations, untuk keberhasilan publisitas, juga membutuhkan pengertian dan penguasaan tentang strategi membangun hubungan dengan media.
\end{abstract}

Kata kunci: Strategi Public Relations, Media massa

\section{A. Pendahuluan}

Strategi adalah rencana yang
cermat mengenai kegiatan untuk mencapai sasaran khusus (KBBI, 2008: 1340). Sedangkan strategi komuikasi adalah sesuatu yang patut dikerjakan demi kelancaran komunikasi (KBBI, 2008:1341).

Mengacu pada defenisi tersebut maka yang dimaksud dengan strategi membangun hubungan dengan media adalah satu rencana yang cermat dalam membangun hubungan dengan media dalam rangka menciptakan hubungan yang baik dalam media massa. Hubungan baik dengan media massa ini dibangun dengan menggunakan strategi komunikasi yang tepat, yaitu cara yang dilakukan demi kelancaran komunikasi antara public relations dengan media massa. Hubungan baik yang dimaksud disini adalah hubungan baik dengan 
institusi media dan antara public relations dengan wartawan.

Cara dan strategi yang tepat digunakan oleh seorang public relations dalam menciptakan dan membangun hubungan yang baik dengan institusi media dan dengan wartawan akan mempengaruhi keberhasilan publisitas yang dilakukan oleh public relations.

Pesan-pesan yang disampaikan oleh public relations, baik dalam bentuk berita, feature maupun iklan akan direspons dengan baik oleh institusi media dan wartawan. Imabsnya, pesanpesan yang dikirimkan oleh public relations ke media massa tersebut akan dipublikasikan kepada khalayak. Hasil akhir inilah yang diharapkan oleh setiap praktisi public relations.

Pemahaman tentang apa dan bagaimana strategi public relations dalam membangun hubungan dengan media merupakan hal yang sangat penting bagi praktisi public relations. Keberhasilannya dalam melakukan tugas ke-PR-an dalam rangka menjangkau perhatian khalayak, sangat ditentukan oleh pemahamannya tentang strategi membangun hubungan dengan media serta kepandaian dan taktik mereka dalam membangun hubungan dengan media.

Ada beberapa alasan mengapa seorang public relations harus memiliki pemahaman yang tepat tentang strategi membangun hubungan dengan media (Darmastuti, 2012 :154) :

1. Fakta menunjukkan bahwa $90 \%$ informasi yang dikirimkan oleh public relations ke media massa masuk ke tong sampah. Kondisi ini jelas sangat menyedihkan bagi praktisi public relations. Hasil karya yang dikerjakan dengan susah payah ternyata hanya masuk ke tong sampah. Penyebab berita yang dikirim oleh public relations ke media massa itu ditolak memang bermacam-macam. Bisa jadi penolakan itu disebabkan tulisan yang dibuat oleh public relations kurang berkualitas, atau tulisan yang dibuat oleh public relations sekadar iklan sehingga hanya menguntungkan pihak perusahaan dan tidak ada kepentingan sama sekali dengan masyarakat. Yang lebih parah lagi, sering kali tulisan itu ditolak oleh media massa disebabkan tidak mempunyai hubungan yang baik dengan media massa tersebut.

Kalau alasan pertama dan kedua menjadi penyebab tulisan public relations ditolak dan tidak bisa dipublikasikan, hal itu masih bisa diterima. Tetapi kalau yang menjadi penyebab adalah alasan ketiga, "public relations tidak memiliki hubungan baik dengan pihak media massa", maka itu menjadi alasan yang sangat menyedihkan. Berdasarkan fakta ini 
maka dibutuhkan hubungan yang baik antara public relations dengan media massa.

2. Hubungan yang baik antara public relations dengan media massa sangat mempegaruhi publikasi yang dikirimkan oleh public relations ke media massa. Fakta ini tidak bisa kita pungkiri ketika kita melihat fenomena yang ada di lapangan. Pesan yang dikirim oleh public relations ke media massa (baik itu dalam bentuk news, advertorial, maupun iklan), akan diberitakan oleh media massa atau tidak sangat ditentukan oleh hubungan yang baik antara public relations dengan media massa (baik dengan institusi medianya maupun dengan wartawannya). Berdasarkan fakta ini maka dibutuhkan hubungan yang baik antara public relations dengan media massa.

Dari kedua alasan diatas, hubungan yang baik dengan media massa menjadi satu hal yang sangat penting bagi seorang public relations. Seperti tentara yang akan maju untuk berperang, dia membutuhkan pengertian dan penguasaan tentang strategi perang. Begitu juga dengan praktisi public relations, untuk keberhasilan publisitas, juga membutuhkan pengertian dan penguasaan tentang strategi membangun hubungan dengan media.

\section{B. Strategi Public Relations dalam Membangun Hubungan Dengan Media}

Seorang public relations akan dapat melakukan tugas-tugasnya dengan baik (termasuk dalam melakukan media relations) kalau didukung oleh strategi komunikasi yang tepat dan efektif. Sayangnya, public relations sering kali mengalami kegagalan dalam melakukan media relations, bukan karena public relations tidak mengerjakan kegiatan media relations, tetapi karena public relations tidak tahu apa itu strategi komunikasi dan bagaimana stratrgi komunikasi dalam media relations ini. Adapun strategi komunikasi public relations dengan media, (Soemirat dan Ardianto, 2003:23) adalah :

1. By serving the media (pelayanan kepada media)

Strategi dengan membeikan pelayanan kepada media. Seorang public relations dituntut untuk selalu siap memberikan pelayanan kepada media sesuai yang dibutuhkan oleh media massa tersebut. Pelayanan kepada media massa ini dapat berupa menyiapkan jawaban-jawaban serta memberikan jawaban maupun informasi yang dibutuhkan oleh media massa pada saat-saat tertentu yang berhubungan dengan informasi 
tentang perusahaan atau institusi tempat mereka berada. Pelayanan kepada media ini biasanya dilakukan pada saat perusahaan sedang mengalami masalah atau pada saat perusahaan sedang berada di puncak (sedang sukses). Biasanya perusahaan atau organisasi akan menjadi sumber berita yang menarik.

Pelayanan lain yang harus diberikan oleh public relations kepada media massa adalah pelayanan untuk memberikan salinan pers (press release). Dalam segala situasi (baik itu dalam situasi yang tidak menguntungkan bagi perusahaan maupun pada saat ada berbagai event tertentu), seorang public relations harus selalu siap melayani media ketika media massa tersebut membutuhkan salinan pers.

2. By establishing a reputations for reliability (menegakkan reputasi perusahaan agar tetap di percaya)

Strategi yang dilakukan oleh public relations sebagai upaya untuk menegakkan reputasi perusahaan supaya perusahaan/organisasi tersebut tetap dapat dipercaya. Untuk membangun masyarakat, perusahaan atau organisasi tidak hanya bisa mengandalkan promosi atau memasang iklan di media massa.
Perusahaan atau organisasi harus melakukan kegiatan untuk membangun reputasi perusahaan supaya tetap dipercaya oleh masyarakat.

Ada banyak cara yang dapat dilakukan untuk reputasi suatu perusahaan. Kegiatan pertama yang dapat dilakukan adalah membuat tulisan yang dikirimkan ke media massa. Tulisan bisa berupa berita maupun informasi tentang perusahaan yang dapat ditulis dalam bentuk straight news maupun feature. Cara lainnya adalah dengan melakukan kegiatan sosial kepada masyarakat, yang kemudian dipublikasikan dengan menggunakan media massa.

Selain menggunakan publikasi yang tidak menggunakan data, publisitas lainnya dapat dilakukan dengan menggunakan dana. Cara yang bisa dilakukan ini adalah dengan membuat iklan. Informasi tentang perusahsaan atau organisasi bisa dibuat dalam bentuk tulisan corpotorial. Informasi tentang kegiatan-kegiatan positif yang dilakukan oleh perusahaan maupun kegiatan-kegiatan pengabdian masyarakat sebagai bentuk tanggung jawab sosial (social responsibility) perusahaan bisa ditulis dalam bentuk artikel berupa opini atau pendapat tentang suatu permasalahan. 
Supaya masyarakat dapat memercayai tulisan opini atau pendapat ini maka perusahaan atau organisasi harus menyediakan orang-orang yang memiliki kredibilitas dalam bidang tersebut. Strategi ini bisa dilakukan dengan menyediakan narasumber yang kredibel dalam memberikan jawaban untuk kasus-kasus tertentu atau bisa juga dengan menyediakan pakar-pakar yang ada di perusahaan tersebut untuk membantu menyelesesaikan permasalahan yang ada di masyarakat.

Strategi lain yang dapat digunakan public relations adalah strategi dengan memberikan klarifikasi apabila perusahaan atau organisasi itu sedang mengalami suatu permasalahan. Klarifikasi dapat didukung dengan menunjukkan fakta-fakta yang sesungguhnya.

3. By supplying good copy (memasok naskah informasi yang baik)

Strategi dengan memasok naskah informasi yang baik. Naskah informasi dapat dibuat dalam bentuk artikel yang berupa opini atau pendapat tentang suatu permasalahan. Naskah informasi yang baik bisa diberikan berdasarkan data-data yang sebenarnya. Naskah bisa disertai dengan gambar atau foto. Dengan memberikan naskah yang baik yang disertai dengan pembuatan teks dan gambar atau foto yang baik, diharapkan bisa menjadi satu strategi untuk menarik perhatian massa.

Selain pengiriman naskah informasi, staregi by supplying good copy ini dapat dilakukan dengan cara pengirian news release yasng baik. Tujuannya supaya release yang dikirimkan dapat dimuat dan sesuai dengan 'selera' media massa maka seorang public relations tidak harus melakukan revisi yang banyak. Dia hanya memerlukan sedikit penulisan ulang atau menyuntingnya.

4. By cooperations in providing material (kerjasama dalam menyediakan bahan informasi)

Strategi yang dilakukan dengan kejasama yang baik dalam menyediakan bahan informasi. Yang menjadi penekanan strategi ini adalah penghargaan yang tinggi dari seorang public relations kepada media massa, termasuk pekerja media. Maksudnya seorang public relations dituntut untuk menghargai media massa serta pekerja media dengan menyediakan waktu yang tepat dan meghargai kedatangan mereka. 
5. By providing verification facilities (menyediakan fasilitas)

Strategi memikirkan fasilitas yang harus disediakan bagi pekerja-pekerja media. Tujuannya adalah agar pekerja media massa merasa nyaman dalam bekerja, yaitu ketika mereka melakukan liputan terhadap perusahaan tempat public relations itu berada. Cara yang dilakukan untuk menerapkan strategi ini adalah dengan memberikan fasilitas kepada pekerja media dan wartawan apabila mereka membutuhkan ruangan untuk melakukan liputan di organisasi atau perusahaan tersebut. Fasilitas ini termasuk fasilitas internet yang dibutuhkan wartawan pada saat mereka meliput berita di perusahaan tersebut.

6. By building personal relationship with the media (membangun hubungan secara personal dengan media)

Strategi ini merupakan strategi yang dilakukan dengan membangun hubungan secara personal antara public relations dengan media massa (baik itu orang-orang yang ada di institusi media maupun dengan wartawan dan pekerja media lainnya). Hubungan personal yang baik antara public relations dengan pekerja media diharapkan dapat digunakan sebagai dasar untuk membangun keterbukaan dan saling menghormati antar profesi masing-masing.

Dalam strategi ini, seorang praktisi public relations dapat membangun hubungan personal yang baik dengan orang-orang yang berada di institusi media maupun dengan wartawan dan pekerja melalui sms, e-mail, atau pesan-pesan dengan menggunakan media sosial untuk menyapa dan menanyakan kabar pekerja media. Strategi yang lain adalah dengan memberikan informasi dan ide-ide yang dapat digunakan sebagai masukan ketika pekerja media ini akan membuat bahan pemberitaan.

Strategi ini merupakan strategi yang sangat diperlukan dalam membangun hubungan dengan media. Hubungan yang baik dengan pekerja media, saling mengerti, saling memahami, dan saling menghormati antara profesi public relations dengan media merupakan salah satu kunci dalam keberhasilan media relations yang dilakukan oleh praktisi public relations. Berdasarkan fakta di lapangan, dari keenam strategi ini, antara satu strategi dengan strategi lain saling terkait dan saling membutuhkan. Apabila seorang praktisi public relations ingin tugas ke-PR-annya berjalan dengan efektif maka harus 
mengunakan keenam strategi tersebut untuk melaksanakan tugasnya dengan saling terkait antara satu strategi dengan strategi yang lain.

\section{Model Hubungan Public Relations dengan Media Massa}

Praktisi public relations dalam membangun hubungan dengan media massa memerlukan strategi. Adapun strategi yang digunakan oleh praktisi public relations adalah duah buah strategi yang digambarkan dalam bentuk model (Darmastuti, 2012:163), yaitu :

\section{Model hubungan antara public relations dengan institusi media}

Model hubungan antara public relations dengan institusi media ini adalah model hubungan yang bersifat bisnis. Hubungan dibangun dalam kondisi formal dan saling menguntungkan. Model hubungan ini disebut dengan model 'imbalanced komentalisme relationship'. Model imbalanced komentalisme relationship ini diambil dari kata "komentalisme" yang artinya adalah kondisi yang memungkinkan antara dua mahluk hidup yang hidup bersama, tanpa saling merugikan antara satu dengan yang lain. Kata "imbalanced" sendiri menunjukkan bahw efek yang diberikan di antara keduanya tidak seimbang. Dari pengertian dua kata tadi maka model imbalanced komentalisme relationship ini menggamabarkan hubungan antara mahluk hidup yang hidup bersama, tanpa saling merugikan antara satu dengan yang lain, tetapi dalam hubungannya yang tidak seimbang.

Model hubungan ini terjalin dalam hubungan saling terikat antara satu dengan yang lain, tetapi tidak merugikan antara satu dengan yang lain (simbiosis komensalisme). Contohnya : public relations memasang iklan di media, sebaliknya media memuat berita yang dikirimkan oleh public relations. Hubungan ini adalah hubungan yang formal dan kekeluargaan, tetapi berada dalam konteks bisnis. Ketidakseimbangan terjadi dalam hal pemasokan berita. Institusi media cenderung mengharapkan public relations yang selalu aktif menyuplai berita dan berpartisipasi dalam memasang iklan di media, sedangkan media tidak mempunyai konsekuensi timbal balik dalam hubungan ini (hubungan formal dalam bentuk bisnis) - imbarlanced komentalisme.

Jika digambarkan maka model hubungan tersebut seperti hubungan antara ikan pari dengan ikan remora (ikan kecil). Ikan remora dapat 
berlindung di bawah ikan pari sehingga ikan remora mendapat keuntungan dari ikan pari. Sedangkan ikan pari sendiri tidak mendapat keuntungan apa pun dari ikan remora.

Dari gambaran tentang model hubungan antara public relations dengan institusi media yang digambarkan dengan ikan pari dan ikan remora, jika dilakukan analisis dengan mengacu pada pendapat Grunig maka model hubungan antara public relations dengan institusi media adalah model hubungan mixed asymeric-symetric model. Model hubungan ini adalah model hubungan yang terjalin dalam hubungan samasama menguntungkan (simbiosis mutualisme-symetric model). Model hubungan ini dapat diaplikasikan dalam kegiatan kehumasan seharihari, contohnya public relations dapat memasang iklann di institusi media, sebaliknya media massa memuat berita yang dikirimkan oleh public relations. Di sisi yang lain media massa juga berharap praktisi public relations akan bekerjasama, bersikap, dan berpikir sesuai dengan apa yang diharapkan oleh institusi media (asymetric model). Hubungan ini adalah hubungan yang formal dan kekeluargaan tetapi dalam konteks bisnis.
2. Model hubungan antara seorang public relations dengan pekerja media (termasuk wartawan)

Model hubungan antara seorang public relations dengan pekerja media (termasuk wartawan) adalah hubungan yang mengarah pada model two way symetrical, meskipun dalam hubungan ini public relations masih banyak berfungsi sebagai pemberi informasi (public information). Ini terlihat dari model hubungan yang informal, hubungan sebagai sahabat, hubungan simbiosis mutualisme, dan saling mempercayai. Untuk menciptakan hubungan seperti ini, seorang praktisi public relations diharapkan dapat memberikan informasi yang dibutuhkan pekerja media, termasuk wartawan dalam mencapai kepentingan bersama. Model ini bisa disebut dengan Model Harmonious Mutualisme Relationship, yaitu sebagai model gabungan antara model two way symetric dan public information (combined two-way symetric \& public information model).

Kata "harmonious" diambil dari kata harmony yang berarti adanya keselarasan hubungan antara public relations dan pekerja media, juga dengan wartawan. Sedangkan kata "mutualisme" menunjukkan bahwa antara public relations dengan pekerja 
media dan dengan wartawan mempunyai hubungan yang saling menguntungkan satu dengan yang lain.

Apabila kita analisis berdasarkan model yang dipetakan oleh Grunig, Model Harmonious Mutualisme Relationship adalah model hubungan combined symetric-public information model, yaitu model hubungan persahabatan dalam konteks simbiosis mutualisme dimana terjadi proses saling mempercayai dan saling membantu. Hubungan ini adalah hubungan yang informal dan pertemanan, bahkan dapat disebut sebagai hubungan persahabatan yang saling menguntungkan dan tidak ada jarak antara pekerja media temasuk wartawan dengan public relations.

Model hubungan yang lebih tepat bagi seorang public relations dalam membangun hubungan yang baik dan efektif dengan media massa adalah model hubungan yang dibangun dengan institusi media dan pekerja media, yaitu Model Harmonious Mutualisme Relationship.

Dalam melakukan pendekatan kepada institusi media dan pekerja media dibutuhkan strategi, yaitu strategi dengan membangun hubungan persahabatan, saling pengertian, saling memahami, dan saling menguntungkan.

\section{Reciprocity Model}

Dalam pendekatan sosial, ada satu pendekatan yang sesuai untuk memahami hubungan antara public relations dengan media massa ini, yaitu pendekatan yang sering dikenal dengan Reciprocity. Serge-Christophe Kolm, seorang ahli sosial, mengatakan bahwa resiprositas merupakan dasar dalam relasi sosial, seperti penjelasan yang dia berikan dalam bukunya yang berjudul Reciprocity: An economics of social relations, Serge mengatakan bahwa :

Reciprocity is the basis of social relations. It permits a peaceful and free society in which people and rights are respected. The essence of families and communities, it also enables the working of markets and organizations, while correcting their main failures. Reciprocity is also a basis of politics and it justifies social policies (Serge, 2008:3).

Dalam pandangan Serge, reciprocity yang dianggap sebagai dasar dalam hubungan sosial dapat menciptakan suatu perdamaian dimana kebebasan dan kebenaran setiap orang sangat dihargai. Dalam hubungan ini, kekeluargaan menjadi satu penekanan dimana masing-masing anggota memiliki kesadaran untuk mengoreksi kesalahan mereka sendiri. Bahkan, reciprocity juga 
digunakan sebagai dasar politik dan dasar dalam mencari keadilan dalam politik sosial.

Kalau dilihat dari pengertiannya, reciprocity merupkan " $A$ situation in which two people, countries, etc. Provide the same help or advantages to each other" (A.S. Hornby dalam Darmastuti, 2012 : 170). Defenisi ini menunjukkan bahwa hubungan yang terjalin dalam pengertian reciprocity ini adalah hubungan yang saling menguntungkan antara satu pihak dengan pihak lain dalam nuansa altruism.

Luigino Bruni dalam bukunya yang berjudul Reciprocity, Altruism and the Civil Society: In praise of heteroginity mengatakan bahwa dalam pandangan reciprositas ini suatu hubungan dilakukan secara sukarela. Masing-masing anggota memperlakukan orang lain seperti orang lain memperlakukan mereka. Hubungan dilakukan dalam tindakan, tingkah laku atau perasaan, dengan pengetahuan sosial tradisional yang membatasinya. Pemahaman ini seperti yang ditulis oleh Luigino Bruni berikut ini.

"Reciprocity is treating other people as other people treat you, voluntarily and not as result of a binding exchange agreement. It concerns acts, attitude or sentiments, and the tradition of social science restricts the term to favourable items (to which revenge and retaliation are only very partially symmetrical, as we shall see)" (Luigino Bruni, 2008:6)
Menurut Luigino ada dua fenomena yang sangat mempengaruhi dalam resiprositas. Yang pertama adalah rasa terima kasih dan yang kedua adalah menirukan. Fenomena yang pertama menjadi hal yang paling disukai dalam hubungan ini, tetapi dibutuhkan satu tindakan untuk menyeimbangkan atau penyesuaian di antara kedua pihak. Adanya penyesuaian ini akan menimbulkan perasaan timbal balik. Fakta yang kedua adalah menirukan. Tindakan menirukan ini akan memberikan keuntungan secara luar biasa sebagai timbal balik dari suatu perbuatan yang ditujukan kepada seseorang dan yang menguntungkannya. Sebagai gantinya, orang yang melakukannya menjadi dikenal baik dan ini menjadi suatu keuntungan yang diterima, hal ini disebut sebagai peniruan gambar kaca secara kuat (strong mirror-image imitation) (Luigino Bruni, 2008:6).

Luigino Bruni juga menambahkan, "Reciprocity as a set of motivationally interrelated gifts or favours has been considered and studied by a long and rich tradition in social science". Inilah yang menjadi kelebihan dari hubungan dalam model reciprocity ini. Di dalam model hubungan ini, antara satu dengan yang lain saling memotivasi sehingga memperkuat hubungan yang terjadi. Model hubungan inilah yang lebih tepat 
digunakan dalam memetakan dan menggambarkan hubungan antara public relations dengan media massa (institusi media dan pekerja media).

\section{E. Penutup}

Strategi dalam mejalin hubungan yang harmonis dengan media massa adalah hal yang sangat penting bagi praktisi public relations. $\mathrm{Hal}$ ini disebabkan karena media massa merupakan media yang sangat vital dalam membantu keberhasilan seorang public relations menyampaikan pesan atau informasi serta publikasi tentang perusahaan atau organisasi kepada publik. Untuk itu hubungan antara public relations dengan media masa dalam hal ini termasuk institusi media dan pekerja media hendaknya selalu terjalin dengan harmonis.

\section{F. Daftar Pustaka}

Bruni, Luigino, 2008. Reciprocity, Altruism and the Civil Society: In praise of heterogeneity. New York: Routledge.

Darmastuti, Rini. 2012. Media Relations Konsep, Strategi \& Aplikasi. Yogyakarta: CV. Andi Offset

Departemen Pendidikan Nasional. 2008. Kamus Besar Bahasa Indonesia
Pusat Bahasa. Ed. 4. Jakarta: PT Gramedia Pustaka Utama

Serge Christophe Kolm, 2008. Reciprocity: An economics of social relations. New York: Cambridge University Press.

Soemirat Soleh \& Ardianto Elvinaro, 2003. Dasar-dasar Public Relations. Bandung: PT. Remaja Rosdakarya Offset. 